\title{
Financial Sector Development and Economic Growth in Bangladesh: A Factor Analysis Based Causality Approach
}

\author{
Altaf Hossain ${ }^{1}$, Suman Biswas ${ }^{1}$, Md. Nasif Hossain ${ }^{1} \&$ Arnab Kumar Poddar ${ }^{1}$ \\ ${ }^{1}$ Department of Statistics, Islamic University, Kushtia-7003, Bangladesh \\ Correspondence: Suman Biswas, Department of Statistics, Islamic University, Kushtia - 7003, Bangladesh. Tel: \\ 88-017-4142-2147. E-mail: suman.iu09@gmail.com
}

Received: April 7, 2017

doi:10.5539/ijef.v9n8p229
Accepted: July 7, 2017

Online Published: July 25, 2017

URL: https://doi.org/10.5539/ijef.v9n8p229

\begin{abstract}
To understand the finance-growth nexus, this paper is intended to find a fewer number of important financial factors using Factor Analysis on some selected indicators of Bangladesh financial sector during the period 1988-2013. This paper then tries to check whether the identified financial factors cause economic growth or economic growth causes financial factors using the Granger - Causality test. Factor Analysis shows that financial indicators under the dimensions, depth and stability form Factor 1, and the indicators under the dimensions, use/access and efficiency form Factor 2. Being consistent with economic sense, Granger - Causality test shows that no financial factor significantly causes economic growth; rather economic growth causes "depth/stability" ('private credit + capitalization' /non-performing loan) factor of financial sector during the period. In summary, on average, financial sector of Bangladesh is being unstably (being increased non-performing loan) deepened with response to the demand of economic growth since 1988.
\end{abstract}

Keywords: finance - growth nexus, factor analysis, depth/stability, efficiency/accessibility, Bangladesh

\section{Introduction}

The debate on the relationship between financial sector development and economic growth has been going on since 1911. Until about 1990, there were few economists, especially Joseph Schumpeter, who believed that financial sector development has a significant impact on economic growth. Joan Robinson and some other economists thought that financial sector was developed with response to the demand of economic growth until the early 1990s. The direction that finance causes growth is called supply leading relationship; whereas the demand following relationship refers to the opposite direction that finance follows growth. Until now, economists are deeply divided on the issue and disproportionated or unverified use of different statistical methods fuel it to continue. It is evident that Schumpeter (1911) was the first person who worked with the relationship. Broadly speaking, there are two sides of financial development - one is banking sector and another is stock market; where the banking sector development has more contribution than the stock market development in accelerating economic growth, especially for developing countries like Bangladesh. Many empirical studies, e.g., Levine (1997, 2005) and Wachtel (2001) reached a conclusion that the financial sector development improves economic growth. Levine (2005) recommended that financial sector can accelerate economic growth through several channels.

Using firm - level data on corporate financing Oura (2008) examined the efficiency of different sections of India's financial system. Empirical analyses indicate the inefficiency of the financial system of India in channeling fund into industries with higher external finance dependence. Ndlovu (2013) examined the causal and cointegration (long run) relationship between financial sector development and economic growth in Zimbabwe. He found the existence of demand following relationship that economic growth causes financial sector development in Zimbabwe. The paper demanded the relationship to be the supply leading that financial sector development spurs economic growth in Zimbabwe. For that this paper recommended that Zimbabwe should focus on trade liberalization and other related activities. Using annual data from 1980-2010, Sami (2013) showed that there is long run relationship between banking sector development, remittances and economic growth in Fiji. In addition, causality analysis indicates causality from economic growth and remittances to banking sector development in Fiji. Ray (2013) also examined the finance-growth nexus in India from 1990 to 2011. He showed that financial sector development causes economic growth. He measured the development of financial sector by ratio of gross domestic capital formation to GDP, ratio of gross domestic savings to GDP, etc. Saad (2014) found bidirectional Granger 
causality between financial sector development and economic growth; showing the relationship is positive in the short run and is insignificant in the long run in Lebanon. Shahbaz et al. (2015) revisited the relationship in Bangladesh using quarter frequency data from 1976 to 2012. They empirically proved that financial sector development accelerates economic growth in Bangladesh but capitalization hampers it. Hossain et al. (2015) investigated the finance - growth nexus of Bangladesh during the period of 1990-2013 and found that not the stock market but only banking sector significantly causes GDP growth.

On the other hand, some economists, for example Lucas (1988), Chandavarkar (1992) deny the importance of finance - growth relationship. Lewis (1955) and Patrick (1966) suggest a two way relationship: both the supply leading and the demand - following. The presence of sound financial sector policies is very much important. The lack of these policies could have catastrophic outcome, as illustrated by the global financial crisis. Financial sector development has heavy implication on economic development - both when it functions and malfunctions. There are some influential articles on the potential dangers of large financial sectors and they are, for example, Tobin (1984), Rajan (2005) and Johnson (2009). With strong empirical backing, Arcand et al. (2012) showed the marginal effect of financial sector development on economic growth turns into a negative one when the size of credit to the private sector is excessive. The size is called excessive when it exceeds about 100 percent of GDP. Many developed and developing countries liberalized their financial system especially the banking; as a result, they suffered from consecutive and devastating baking crises leading to a huge decline in the level of economic growth (Rachdi, 2014). Overall, it is also likely to get any types of relationships depending on other economic conditions of the respective countries. The types of the relationships can be a positive, negative, no association or negligible (Guryay et al., 2007).

Though financial depth is popularly used dimension, it is not the only dimension for characterizing a sound and well - functioning financial system. Access, efficiency and stability along with financial depth form a framework identified by the World Bank's Global Development Database. Both the financial institutions (mainly banking) and financial markets (mainly stock market) have the above four dimensions. Since there are many indicators, importantly, private sector credit, stock market capitalization, number of listed companies, interest rate spread, turnover ratio and non-performing loan categorized in the four dimensions, so it is another big challenge to choose one or two important factors to measure the development of financial sectors.

To keep the study as simple as possible, most of the existing studies, especially, the studies in respect of Bangladesh have considered only one or two indicators or dimensions (individually) to explain the whole financial sector and then tried to find out their role in economic growth. But it is not enough to consider only one or two indicators for the whole sector. Although it is very difficult to explain the relationship, we should consider more indicators or dimensions of financial sectors because they have some interaction effects on economic growth and can give different results. To make this difficult job possible, factor analysis can be incorporated in the analysis of finance - growth nexus. Keeping the interaction effects in count, this factor analysis can be used to convert many original indicators (importantly, private sector credit, stock market capitalization, number of listed companies, interest rate spread, turnover ratio and non-performing loan) or dimensions into a few factors (one or two). Considering one important (determined by existing researches) indicator from each dimensions of each sectors, the objectives of this study regarding the finance - growth relationships of Bangladesh are as follows: (1) Identifying the important factors, in a smaller number, those explain the development of financial sector of Bangladesh the most by using a factor analysis, and (2) Determining the direction of causality between the identified financial factor (s) and economic growth of Bangladesh. As far we know, nobody implemented the same objectives especially in Bangladesh.

The remaining part of the paper is organized as follows. In section 2, data source and variable are described. Appropriate research methodologies are presented in section 3 in detailed. Section 4 interprets and discuss about the results. Finally, conclusion is drawn on the basis of a rigorous summary in section 5 .

\section{Data and Variable Description}

The annual data set is extracted from the World Development Indicators (of World Bank Database) on Bangladesh, for the time period of 1988-2013. The real per capita GDP growth as a measure of economic growth is used in this study. Selected financial variables or indicators of the Bangladesh financial sector are categorized under the four dimensions named financial depth, access, efficiency, and stability as follows. The ratio of domestic credit (\% of GDP) to the private sector by Bank (DCPB) and the ratio of Market Capitalization to GDP (MC) belong to the dimension of financial depth. Financial access is measured by the number of listed companies per million people (NLC). Interest rate spread (Lending rate- deposit rate, \%) (IRS) and the ratio of stock market turnover or value traded/capitalization (TOR), are used to measure the financial efficiency. Bank non-performing loan to total gross 
loans (NPLs) belong the dimension of financial stability. The selected variables are common in most of the existing studies.

\section{Research Methodologies}

\subsection{Unit Root Test}

In time series analysis, stationary indicates that the mean and variance of the series are not dependent on time. A series is said to be non-stationary or unit root if the mean and variance of the series vary overtime. Non-stationarity can be removed by differencing the series several times, e.g. $k$ times, then it is said to be integrated of order $k$, denoted by $\mathrm{I}(\mathrm{k})$. But if a series does not need to be differenced then it is donated by $\mathrm{I}(0)$ and said to be stationary. The stationarity condition of a time series can be scrutinised using Dickey-Fuller (DF), (1979) Unit root tests; which tests the null hypothesis of whether a unit root is present in an autoregressive model. The alternative hypothesis is different depending on which version of the test is used, but is usually stationarity or trend-stationarity. A simple AR (1) model,

$$
y_{t}=\rho y_{t-1}+u_{t}
$$

Where, $y_{t}$ is the variable of interest, $t$ is the time index, $\rho$ is a coefficient and $u_{t} \sim$ i.i.d $N\left(0, \sigma^{2}\right)$. If $\rho<1$ the model is assumed to be stationary and the characteristic polynomial of the AR (1) process lies the unit circle, otherwise it is non-stationary and the variance of the series increases overtime.

The regression model can be written as

$$
\Delta y_{t}=(\rho-1) y_{t-1}+u_{t}=\delta y_{t-1}+u_{t}
$$

Where, $\Delta$ is the first difference operator. In this model, the null hypothesis is that $\delta=0$ which means there is a unit root, i.e. the time series is non-stationary. Where $\delta<0$ is the alternative hypothesis which means the series is stationary. It is important to ensure that the series is stationary for the following factor analysis and granger causality test.

\subsection{Johansen Cointegration Test}

The Johansen test is a testing procedure that tests the cointegrating relationship of more than one series. This test is subject to the large sample properties. If the sample size is small then this testing procedure may not be consistent and in that case one should use Auto Regressive Distributed Lags (Pesaran, Shin, \& Smith, 2001). The test for cointegration can be done to check the existence of a long run relationship among the considered variables if the variables are integrated of same order.

\subsection{Factor Analysis}

Since a financial sector has many indicators categorized in different dimensions and they are correlated in different factors, so it is not enough to consider indicators separately to explain the development of that financial sector and then its marginal effects on economic growth. In this regard, Factor Analysis can be used to find a fewer number of important factors, necessarily less than the number of original indicators to explain the development of financial sector well. Here, one importance of Factor analysis on the considered indicators of financial sector is that it gives a fewer number of factors combining all indicators in each factor. Overall, it creates an opportunity to explain the financial sector with a fewer number of factors and understand the finance - growth nexus relatively well.

The explorative factor analysis for this study is summarized as follows. Similar to the cluster analysis, the factor analysis groups similar variables into dimensions. Often, it is called identifying latent variables. Factor analysis does not distinguish between exogenous and endogenous variables because it is an explorative analysis which groups similar variables into dimensions.

The equation of the factor analysis can be written in matrix form as follows:

$$
Z=\lambda F+\varepsilon
$$

where $\mathrm{Z}$ is a $p \times 1$ vector of financial indicators or variables, $\lambda$ is a $p \times m$ matrix of factor loadings; $\mathrm{F}$ is an $m \times 1$ vector of factors and $\varepsilon$ is a $p \times 1$ vector of error or residual factors (Sharma, 1996). Because of differences in the units of variables used in factor analysis, the variables are standardized and a correlation matrix of variables is used to obtain eigenvalues. Then number of important factors is determined based on the values of eigenvalues or Scree plot. Factors loadings can be estimated different methods like principal component and maximum likelihood methods. Principal component method is used in this study. To smooth the interpretation of 
factor loadings $\left(L_{i k}\right)$, VARIMAX rotation is used. Factor coefficients $\left(C_{i k}\right)$ are used to obtain factor scores for selected factors using regression method. After obtaining factor scores for the determined each factor, the following Granger Causality test is used to understand the directional relationship between financial factors and economic growth of Bangladesh.

\subsection{The Granger Causality Test}

The Granger causality test is mostly used to test the causal relationship of the variables. It works as like a regression model where the lagged values of the dependent variable is used along with other independent variables. For example, to test the causality between Factor 1 and economic growth (GDP) the granger causality test can be written as:

$$
\begin{aligned}
& G D P_{t}=\sum_{i=1}^{n} \beta_{i} \text { Factor }_{t-1}+\sum_{i=1}^{n} \lambda_{i} G D P_{t-1}+\delta_{t}
\end{aligned}
$$

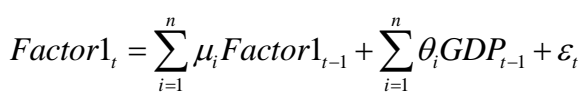

Where $\delta_{t}$ and $\varepsilon_{t}$ are uncorrelated. The details of this testing procedure are left; the interest reader may read the original paper of Granger (1969).

\section{Result and Discussion}

All the variables used in this study are standardized to make them unit free. Abbreviated names of the original variables are then changed to ZGDPG, ZDCPB, ZIRS, ZNPLs, ZMC, ZNLC and ZTOR respectively. To examine stationarity of the used variables in this study, the Graphical method and Dickey-Fuller (DF) test are used to test for unit root.

Figure 1 indicates that all the standardized variables are not stationary. Indication from the Figure 1 needed to be clear more by using Dickey-Fuller (DF) test and results are given in Table 1:
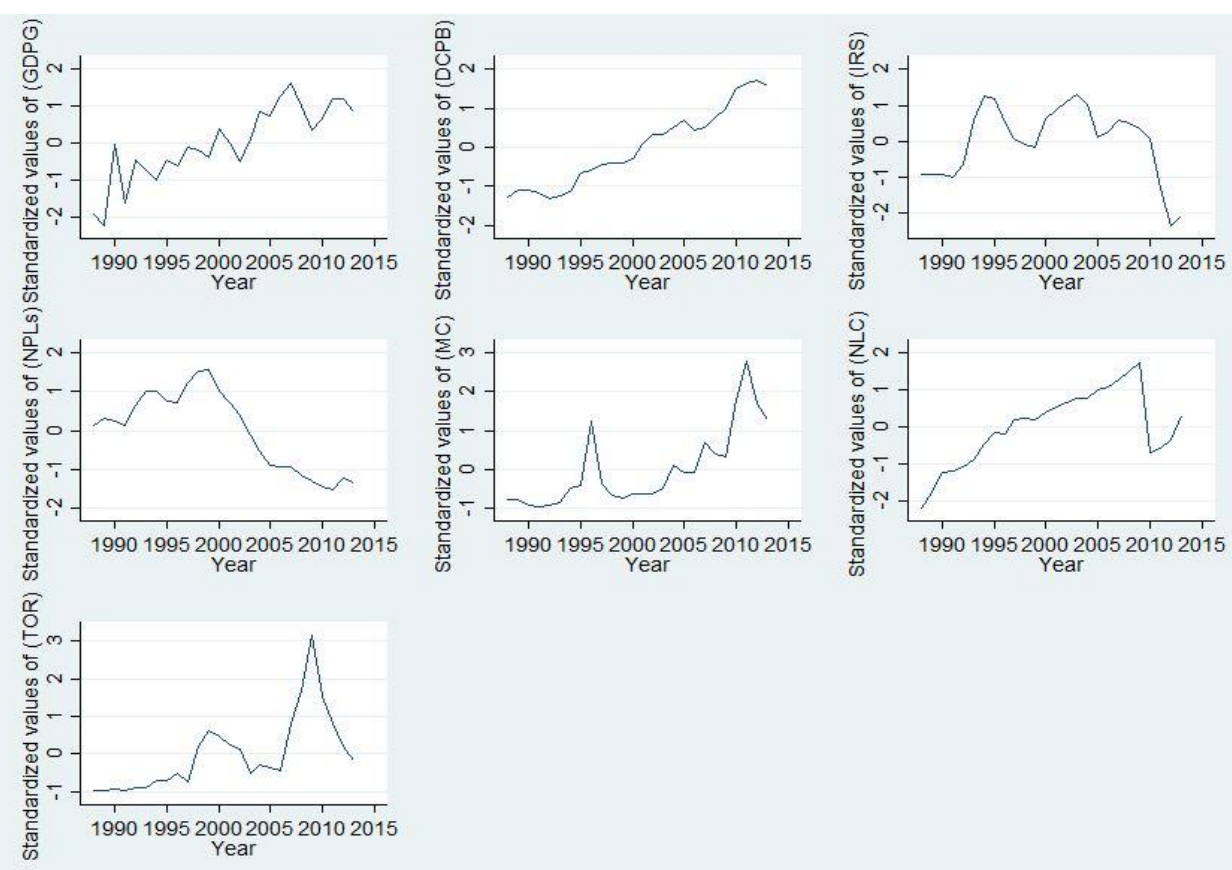

Figure 1. Plot of Standardized data for checking stationary

Table 1 reports that the variables are not stationary at $1 \%$ or $5 \%$ or $10 \%$ level of significance by using DF tests for the standardized variables. 
Table 1. Unit Root (Dickey Fuller) test results of standardized data

\begin{tabular}{cc}
\hline Variables & Test Statistic \\
\hline ZGDPG & -2.429 \\
ZDCPB & 0.070 \\
ZIRS & -0.792 \\
ZNPLs & -0.077 \\
ZMC & -1.569 \\
ZNLC & -2.426 \\
ZTOR & -1.753 \\
\hline
\end{tabular}

Note. $* * * * * / *$ indicates stationary at $1 \% / 5 \% / 10 \%$ respectively.

To make all the variables stationary, first differencing is used for each series or variable. Then DF test results are given in Table 2 and the graphical representation in the Figure 2. Table 2 ensures that all the variables become stationary after first differencing. Stationarity of all the differenced variables is clearly visualized in Figure 2.

Table 2. Unit Root (Dickey Fuller) test results of difference standardized data

\begin{tabular}{cc}
\hline Variables & Test Statistics \\
\hline DZGDPG & $-8.657 * * *$ \\
DZDCPB & $-3.696 * * *$ \\
DZIRS & $-2.863 * *$ \\
DZNPLs & $-2.835^{*}$ \\
DZMC & $-5.469 * * *$ \\
DZNLC & $-4.717 * * *$ \\
DZTOR & $-3.890 * * *$
\end{tabular}

Note. $* * * / * * / *$ indicates stationary at $1 \% / 5 \% / 10 \%$ respectively.

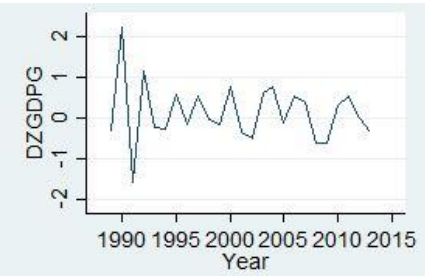
Year
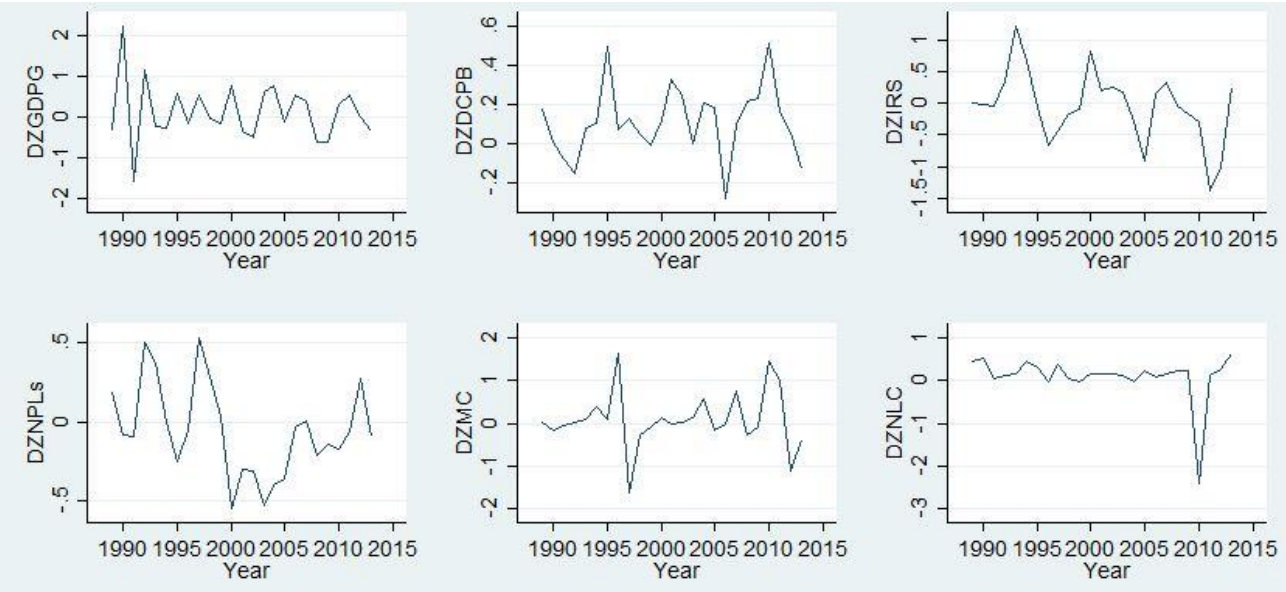

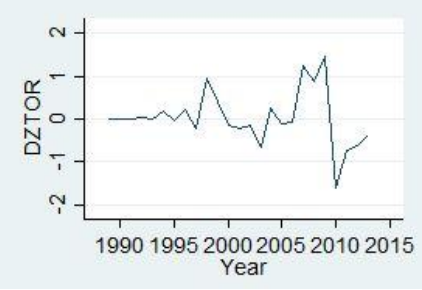

Figure 2. Plot of $1^{\text {st }}$ differenced data 
Table 3. Johansen Cointegration test

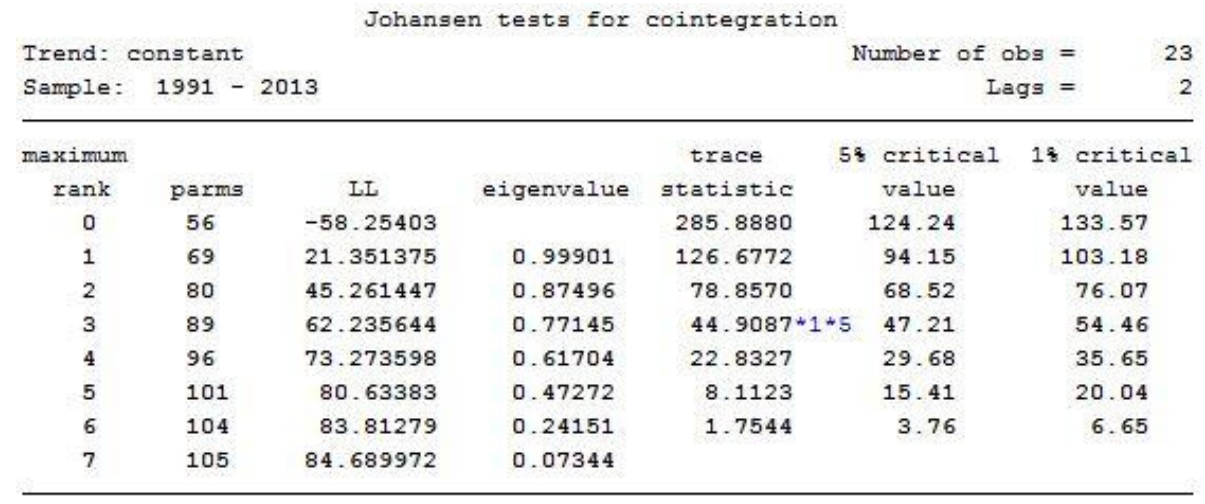

From the results of Table 3 it is seen that three cointegrating equations are significant at $1 \%$ level of significance, though four equations are not significant at all. Since several equations are represented as significant, the variables are cointegrated and they have a long run relationship.

Table 4. Principal component analysis

\begin{tabular}{|c|c|c|c|c|}
\hline Component | & Eigenvalue & Difference & Proportion & Cumulative \\
\hline $\begin{array}{l}\text { Comp1 } \\
\text { Comp2 } \\
\text { Comp3 } \\
\text { Comp4 } \\
\text { Comp5 } \\
\text { Comp6 }\end{array}$ & $\begin{array}{r}2.22012 \\
1.1678 \\
.913925 \\
.746489 \\
.68877 \\
.262891\end{array}$ & $\begin{array}{r}1.05232 \\
.253875 \\
.167436 \\
.0577194 \\
.425878 \\
.\end{array}$ & $\begin{array}{l}0.3700 \\
0.1946 \\
0.1523 \\
0.1244 \\
0.1148 \\
0.0438\end{array}$ & $\begin{array}{l}0.3700 \\
0.5647 \\
0.7170 \\
0.8414 \\
0.9562 \\
1.0000\end{array}$ \\
\hline
\end{tabular}

The Table 4 reports the total explained variance of the factor model using principal component method. The table also includes the eigenvalues of each factor. The eigenvalue is the sum of the squared factor loadings for each factor. STATA extracts all factors that have an eigenvalue greater than 1 . In our case the analysis extracts two factors. This table finally shows the total explained proportional and cumulative variance for each factors. The model explains about $57 \%$ of the total variance with these two factors.

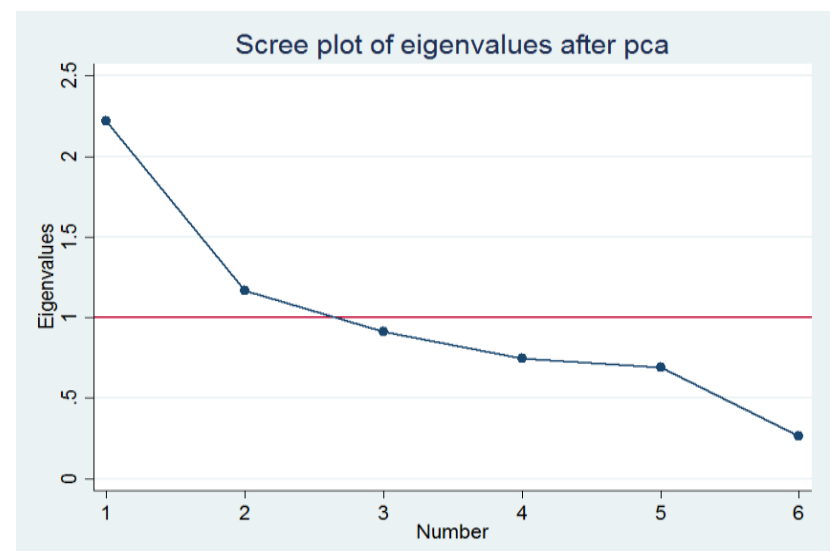

Figure 3. Scree plot after PCA

The eigenvalues for each possible solution are graphically shown in the Scree Plot. As we find with the Kaiser---Criterion (eigenvalue $>1$ ) the optimal solution have two factors which is shown in Figure 3.

The Table 5 and Table 6 respectively show the factor loading matrix and the rotated factor loading matrix. These tables are the key to interpreting the two factors and assigning a name for each of them. The factor loadings that are 
shown in these tables are the correlation coefficients between variable and factors. If a factor loading is less than 0.5 , then the corresponding variable will be kept out and the remaining variables will form a factor. These remaining variables play dominating roles to give a name for the identified factor.

Table 5. Factor loading

\begin{tabular}{|c|c|c|c|}
\hline variable & Factor 1 & Factor 2 & Uniqueness \\
\hline $\begin{array}{l}\text { DZDCPB } \\
\text { DZTRS }\end{array}$ & $\begin{array}{r}-0.6751 \\
0.2739\end{array}$ & 0.1053 & $\begin{array}{l}0.5332 \\
0.5240\end{array}$ \\
\hline DZNPLS & 0.5094 & -0.5606 & 0.4263 \\
\hline DZMC & -0.6887 & 0.3615 & 0.3950 \\
\hline DZNLC & 0.8125 & 0.1785 & 0.307 \\
\hline DZTOR & 0.5434 & 0.5282 & 0.4257 \\
\hline
\end{tabular}

Table 6. Rotated factor loading

\begin{tabular}{|c|c|c|c|}
\hline variable & Factor 1 & Factor 2 & Uniqueness \\
\hline DZDCPB & 0.5950 & & 0.5332 \\
\hline $\begin{array}{r}\text { DZIRS } \\
\text { DZNPLS }\end{array}$ & -0.7472 & 0.6667 & $\begin{array}{l}0.5240 \\
0.4263\end{array}$ \\
\hline DZMC & 0.7645 & & 0.3950 \\
\hline DZNLC & & 0.6437 & 0.3079 \\
\hline DZTOR & & 0.7513 & 0.4257 \\
\hline
\end{tabular}

(blanks represent abs(loading)<.55)

In Table 6 the rotated factor loadings indicate that the DCPB, NPLs and MC load highly on the first factor, forming a "Depth/Stability" dimension.

Table 7. Factor scoring coefficients

\begin{tabular}{r|rr}
\multicolumn{1}{c}{ Variable | } & Factor 1 & Factor 2 \\
\hline DZDCPB | & 0.29450 & -0.11771 \\
DZIRS & 0.23923 & 0.50202 \\
DZNPLS & -0.47755 & -0.23451 \\
DZMC & 0.43528 & 0.05065 \\
DZNLC & -0.19249 & 0.34679 \\
DZTOR & 0.08822 & 0.50667
\end{tabular}

Table 8. Granger causality test

\begin{tabular}{|c|c|c|c|c|}
\hline Equation & Excluded & $\operatorname{chi2}$ & \multicolumn{2}{|c|}{ df Prob > chi2 } \\
\hline DZGDPG & f1 & .92125 & 2 & 0.631 \\
\hline DZGDPG & f2 & 3.1443 & 2 & 0.208 \\
\hline DZGDPG & ALL & 4.1206 & 4 & 0.390 \\
\hline f1 & DZGDPG & 10.737 & 2 & 0.005 \\
\hline f1 & $f 2$ & 10.714 & 2 & 0.005 \\
\hline f1 & ALL & 26.304 & 4 & 0.000 \\
\hline f2 & DZGDPG & 3.1445 & 2 & 0.208 \\
\hline f2 & f1 & 8.733 & 2 & 0.013 \\
\hline f2 & ALL & 11.419 & 4 & 0.022 \\
\hline
\end{tabular}

While NLC, TOR and IRS load highly on the second factor, forming a "Efficiency/Accessible" dimension. Furthermore, the factor scoring coefficients are estimated using regression method and the values are shown in Table 7.

Finally Table 8 reports results of the relationship between two identified financial factor and GDP growth of Bangladesh; where, the first factor, "Depth/Stability" significantly causes second factor "Efficiency/Accessible" and vice-versa. That is, there exist two way relationships between "Depth/Stability" factor and 
"Efficiency/Accessible" factor. Although Gross domestic product per capita growth rate (GDPG) causes first factor "Depth/Stability", it doesn't cause the second factor "Efficiency/Accessible" during the time period of 1988-2013 in Bangladesh.

\section{Summary and Conclusion}

Schumpeter (1911) first addressed the relationship between financial development (broadly, banks and stock markets) and economic growth almost a hundred years ago. Since then it has been the most concerned phenomenon in the area of financial economics (that is, at the nexus point of financial development and economic growth) and a lot of researchers contributed to the area. Unfortunately, there is no consensus on the pattern of the relationship based on empirical evidences. The patterns (both magnitude and direction) of the relationship differ from one time-period/country/region to another and they may be caused by different environmental, political, social and economic events.

Empirical evidences suggest that the relationship can be any of the following types: significant or insignificant, positive or negative, demand - following or supply - leading etc. Another problem is that there are many indicators (importantly, private sector credit, stock market capitalization, number of listed companies, interest rate spread, turnover ratio and non-performing loan) categorized in different dimensions (depth, access/use, efficiency and stability) to measure the development of financial sectors, mainly, banking and stock market.

Most of the existing studies, especially with Bangladesh have considered only one or two indicators or dimensions (individually) to explain the whole financial sector and then tried to find out their role in economic growth. But it is not enough to consider only one or two indicators for the whole sector. So it is important to consider many important indicators and dimensions to explain the development of financial sector and then understand the finance - growth nexus well. Here, factor analysis can be used to convert many original indicators (importantly, private sector credit, stock market capitalization, number of listed companies, interest rate spread, turnover ratio and non-performing loan) or dimensions into a few factors (one or two) along with keeping the interaction effects among different financial indicators or dimensions in count. That is, the identified factors combine all the considered original indicators with their each other interaction effects.

To understand the nexus, this paper is intended to find a fewer number of important factors (where the factors' number is necessarily less than the number of original indicators) using Factor Analysis on some selected indicators of Bangladesh financial sector. This paper then tries to check whether the identified financial factors cause economic growth or economic growth causes financial factors using the Granger - Causality test. The data are extracted from the World Development Indicators of World Bank Database from 1988-2013.

All the variables are standardized to unit free the data. Dickey-Fuller test is used to check the stationarity of all variables. Test results suggest that all the variables are integrated with the same order 1(one) to become stationary. Results of Factor Analysis show that financial indicators under the dimensions, depth and stability form Factor 1, and the indicators under the dimensions, use/access and efficiency form Factor 2. Granger - Causality test shows that the first factor, "Depth/Stability" significantly causes second factor "Efficiency/Accessible" and vice-versa. That is, there exist two way relationships between "Depth/Stability" factor and "Efficiency/Accessible" factor. Financial sector development (both Factor 1 and Factor 2) do not significantly causes per capita GDP growth. That is, the supply - leading relationship between finance and growth is not working in Bangladesh during 1988-2013, which means a significant amount of capital is not accumulated for investment in generating goods and services. Reversely, GDP growth significantly causes only the first factor "Depth/Stability" in Bangladesh during the time period.

Hence the demand following relationship between finance and growth is true here in Bangladesh during the specified period that the financial sector is being developed with response to GDP growth. But the previous works with Bangladesh, covering the same period, especially by Hossain et al. (2015) showed the relationship was supply - leading, which is opposite to the result of this study. In the previous study, indicators of financial sector development were individually considered with GDP growth or interaction effects of them did not take into account whereas this study (current) takes the interaction effects into account using factor analysis. Since the results of factor analysis prove the existence of these interaction effects and that is also justified by experiences of Bangladesh economy during that period, so this (current) study and its results are reasonably accepted. So Economist John Robinson is seemed to be right for Bangladesh that finance (though "Depth/Stability" factor only) follows growth. In summary, on average, financial sector of Bangladesh is being unstably deepened with response to the demand of economic growth since 1988. Policy makers of Bangladesh should make policy so that financial sector is being stably (e.g. limiting non-performing loan) deepened and accelerate economic growth too.

This work is suffered from different limitations. First, the number of observations is small as we collected yearly 
data and were not able to go back to 1988 for Bangladesh. In future I will try to increase the number of observations by using more high frequency data like quarterly and monthly. Secondly, we could have used dynamic factor analysis to keep the dynamic properties of the estimated factor scores; though it does not empirically creates much more significant problems. We will try the dynamic version of the factor analysis in our upcoming works.

\section{References}

Arcand, J. L., Berkes, E., \& Panizza, U. (2012). Too much finance? IMF working paper, 12/161.

BOI. (2015). Board of Investment Bangladesh Prime minister's Office. Retrieved September 15, 2015 from http://www.boi.gov.bd

Chandavarkar, A. (1992). Of Finance and Development: Neglected and Unsettled Questions. World Development, 20, 133-142. https://doi.org/10.1016/0305-750X(92)90142-I

Dickey, D. A., \& Fuller, W. A. (1979). Distribution of the Estimators for Autoregressive Time Series with a Unit Root. Journal of American Statistical Association, 74, 427-81. http://dx.doi.org/10.1080/01621459.1979.10482531

Dickey, D., \& Fuller, W. A. (1981). Likelihood ratio statistics for autoregressive time series with a Unit Root. Econometrica, 49, 1057-72. https://doi.org/10.2307/1912517

Giuliano, P., \& Ruiz-Arranz, M. (2005). Remittances, Financial Development and Growth. IMF Working Paper, Research Department, WP/05/234. http://dx.doi.org/10.5089/9781451862539.001

Granger, C. W. J. (1969). Investigating Causal Relations by Econometric Models and Cross-spectral Methods. Econometrica. 37 (3), 424-438. https://doi.org/10.2307/1912791

Guryay, E., Safkli, O. V., \& Tuzel, B. (2007). Financial Development and Economic Growth: Evidence from Northern Cyprus. International Research Journal of Finance and Economics, 8(27).

Hossain, A., Hossain, N., Biswas, S., \& Podder, A. K. (2015). Banks, Stock Markets and Economic Growth: Evidences from Bangladesh. Annual Banking Conference, 22-23 November 2015, BIBM, Dhaka, 79-86.

Johnson, S. (2009). The quiet coup. The Atlantic (May 2009).

Levine, R. (1997). Financial Development and Economic Growth: Views and Agenda. Journal of Economic Literature, 35, 688-726. Retrieved from http://www.jstor.org/stable/2729790

Levine, R. (2005). Finance and Growth: Theory and Evidence. In P. Aghion, \& S. Durlauf (Eds.), Handbook of Economic Growth (Vol. 1, pp. 865-934).

Lewis, A. (1955). The Theory of Economic Growth. London, Allen and Unwin.

Lucas, R. E. (1988). On the Mechanics of Economic Development. Journal of Monetary Economics, 22(1), 3-42. https://doi.org/10.1016/0304-3932(88)90168-7

Ndlovu, G. (2013). Financial Sector Development and Economic Growth: Evidenec from Zimbabwe. International Journal of Economics and Financial Issues, 3(2), 435-446. Retrieved from http://www.econjournals.com/index.php/ijefi/article/view/401

Nowbusting, B. M., Ramsohok, S., \& Ramsohok, K. (2010). A Multivariate Analysis of Financial Development and Growth in Mauritius: New Evidence. Global Journal of Human Social Science, 10(2), 2-13. Retrieved from http://globaljournals.org/GJHSS_Volume10/ghss_vol10_issue1_ver1_paper7.pdf

Oura, H. (2008). Financial Development and Growth in India: A Growing Tiger in a Cage? IMF Working Paper, Asia and Pacific Department WP/08/79. Retrieved from https://www.imf.org/external/pubs/cat/longres.aspx?sk=21838.0

Patrick, H. T. (1966). Financial Development and Economic Growth in Underdeveloped Countries. Economic Development and Cultural Change, 14, 174-189. https://doi.org/10.1086/450153

Perron, P. (1989). The Great Crash, The Oil Price and The Unit Root Hypothesis. Econometrica, 57(6), 1361-1401. https://doi.org/10.2307/1913712

Perron, P. (1990). Testing for Unit Root in a Time Series with Changing Mean. Journal of Business and Economic Statistics, 8(2), 153-162. https://doi.org/10.1080/07350015.1990.10509786

Pesaran, M. H., Shin, Y., \& Smith, R. J. (2001). Bounds testing approaches to the analysis of level relationship. Journal of Applied Economatrics, 16, 289-326. https://doi.org/10.1002/jae.616 
Rachdi, H. (2014). Finance - Growth Nexus in Presence of Banking Crises: Evidence in High Income and MENA Countries. Journal of Economics and Development Studies, 2(2), 369-384. Retrieved from http://jedsnet.com/journals/jeds/Vol_2_No_2_June_2014/21.pdf

Rajan, R. G. (2005). Has financial development made the world riskier? Proceedings of the 2005 Jackson Hole Conference organized by the Kansas City Fed. Retrieved from http://www.nber.org/papers/w11728

Ray, S. (2013). Does Financial Development Promote Economic Growth in India. International Journal of Economic Practices and Theories, 3(3). Retrieved from http://www.ijept.org/index.php/ijept\%20/article/view/Does_Financial_Development_Promote_Economic_ Growth_in_India/pdf

Saad, W. (2014). Financial Development and Economic Growth: Evidence from Lebanon International Journal of Economics and Finance, 6(8). http://dx.doi.org/10.5539/ijef.v6n8p173

Sami, J. (2013). Remittances, Banking Sector Development and Economic Growth in Fiji. International Journal of Economics and Financial Issues, 3(2), 503-511. Retrieved from http://www.econjournals.com/index.php/ijefi/article/view/275/

Schumpeter, J. A. (1911). A Theory of Economic Development. Harvard University Press.

Shahbaz, M., Rehman, I. U., \& Muzaffar, A. T. (2015). Re-visiting Financial Development and Economic Growth Nexus: The Role of Capitalization in Bangladesh. South African Journal of Economics, 83(3), 452-471; http://dx.doi.org/10.1111/saje.12063.

Tobin, J. (1984). On the efficiency of the financial system. Lloyds Bank Review, 153, 1-15. Retrieved from https://economicsociologydotorg.files.wordpress.com/2014/12/tobin-on-the-efficiency-of-the-financial-syst em.pdf

Wachtel, P. (2001). Growth and Finance: What do we know and how do we know it. International Finance, 4(3), 335-362. http://dx.doi.org/10.1111/1468-2362.00077

\section{Copyrights}

Copyright for this article is retained by the author(s), with first publication rights granted to the journal.

This is an open-access article distributed under the terms and conditions of the Creative Commons Attribution license (http://creativecommons.org/licenses/by/4.0/). 